\title{
What are the Factors that Influence OCB in Hospital Nurses in Malang
}

\author{
Ika Ruhana* \\ Department of Business Administration \\ Universitas Brawijaya \\ Malang, Indonesia \\ *ika_r_fia@ub.ac.id
}

\begin{abstract}
Organizational Citizenship Behaviors (OCB) is extra behaviors performed by a person outside the job description determined by the organization. OCB is very necessary because it has an influence on organizational activities. Hospitals as agencies that prioritize services require optimal roles from their nurses. This study was purpose to determine the Organizational Citizenship Behaviors (OCB), QWL, self-efficacy and organizational commitment of nurses at General Hospital in Malang; to analyze and describe the effect QWL and Selfefficacy on the organizational commitment and nurse's Organizational Citizenship Behavior (OCB) at General hospitals in Malang. This type of research is explanatory research. In this study the population is all nurses who work in 4 General Hospitals in Malang. The numbers of respondents in this study were 175 people. Analysis method used was descriptive analysis and inferential analysis by using GSCA for the sake of analysis needs. The research results showed that QWL and organizational commitment were perceived enough by nurses, Self-efficacy and OCB were perceived well by nurses. Inferential analysis results show that: there are positive and significant influence of QWL on organizational commitment; self-efficacy to organizational commitment, and organizational commitment to OCB. The factors that influence the OCB of nurses in the general hospital in Malang are QWL, self-efficacy and organizational commitment.
\end{abstract}

Keywords-Quality of Work Life (QWL), self-efficacy, organizational commitment, Organizational Citizenship Behavior $(O C B)$, and hospital nurses

\section{INTRODUCTION}

QWL is a very important factor for organizations. An organization has to attempt to improve QWL. QWL is a very complex factors which is a combination between work environment and personality. QWL is essential for an organization to improve the organizational goal. Improving QWL for an employee means to increase productivity and work satisfaction for him [1]

QWL is a multidimensional concept that shows an employee's feeling, including job content, work environment, pay and reward system, training and career development chances, participation in the decision making process, occupational health and safety, organizational and interpersonal relations, and relationship between file on and off the job [1]. A high QWL is essential to attract and keep the employee. There are many studies which have connected between QWL and work satisfaction, organizational commitment, performance, turnover intention etc. [2].

QWL is an aspect from outside of an employee. The researchers add variables from inside of the employee i.e. selfefficacy which will have an impact on his/her behavior in working because every individual has different characteristics. A good coordination between employee and organizational environment will result in a good performance, reduce frustration and minimize employee to do turnover intention, and have a good OCB $[3,4]$.

This research model is built based on Bandura's [5] theory in which a person's behavior is influenced by organizational factors (in QWL research) and person (self-efficacy) that affect work attitudes (organizational commitment) and OCB. OCB is an extra task behavior that is expected to arise in nurses in carrying out their duties. OCB behavior is highly expected by patients and their families as well as highly expected by the hospital to show a good image for the hospital.

Self-efficacy will influence an individual's emotional response. A task will be funny once an employee is competent and confident [6]. Self-efficacy natives from Bandura's Social Cognitive that shows someone's ability to face problem and performance. Self-efficacy shows that cognitive, motivational, and functional process is controlled and managed by an individual's confidence. Self-efficacy has a positive influence on all aspects of life. A vigorous self-efficacy will be effective to achieve personal goal and someone can utilize all his/her effort in achieving his/her goal in dealing with problem and failure [7].

Self-efficacy relates to the organizational commitment and OCB [8-14]. Organizational commitment and OCB is truly needed in an organization. Individual attitude will influence most of their attitude. A positive attitude is expected to result in a positive behavior which finally will benefit an organization in achieving its goal. One of the positive attitudes is realized in the form of organizational commitment. Porter and Lawler [15] 
state that organizational commitment is considered as a willingness of an employee to give a high spirit of work on behalf of an organization, strong willingness to stay in the organization, and goal acceptance and its core value. Commitment reflects a psychological relationship between an individual and an organization [16].

To make an organizational successful, it must have an employee having a great responsibility, an adequate time and energy to successfully work [17]. That amazing attitude is OCB. Organ [18] defines OCB as a behavior which is beyond the normal task of an employee. This includes helping others, escaping from conflict and others which directly or indirectly benefits the organization.

Good QWL is truly needed by an employee. QWL has an impact on his/her performance in working, which is organizational commitment and OCB. Good QWL is also required by a nurse, so he/she is able to have organizational commitment and OCB. The existence of QWL, good organizational commitment and OCB is expected by the nurse to be able to give good service to the client/patient. This research is very interesting to carry out at Hospital Especially General Hospital in Malang, given Malang is the third largest city in East Java having many General Hospitals after Surabaya and Sidoarjo. Analysis unit of this research is a nurse, in which the nurse is one of the components considered important to serve the patient.

This study aims to describe QWL, self-efficacy, organizational commitment and OCB. What factors affect OCB nurses, considering that in the current Covid 19 pandemic conditions OCB nurses are very much needed in providing services to patients and their families.

This paper is organized as follows, section I contains the introduction, section II contains the related work, section III literature review, section IV contain of methodology, section V contain result and discussion, and section IV describes conclusion and future research

\section{RELATED WORK}

This research is based on theory and the result of previous research.

\section{A. The Influence of $Q W L$ on Organizational Commitment}

Organizational Commitment is a level of employee's sacrifice to the organization. An employee will participate in any organizational activities and will influence his/her behavior in the working place [19]. Organizational commitment is an employee attitude and behavioral intention/psychological circumstance of an employee to be ready to make a great effort to maintain membership in an organization. There are many studies conducted to test/relate between QWL and organizational commitment [20-23]. The research result reveals that QWL has a positive and significant influence on organizational commitment. Based on the theory and results of previous research, the hypothesis of this research is:
H1: QWL has a significant effect on organizational commitment

\section{B. The Influence of Self-Efficacy on Organizational Commitment}

High self-efficacy will result in an effective commitment [11]. Self-efficacy has a positive effect on organizational commitment, based on Social Cognitive Theory from Bandura [5], where self-efficacy affects one's behavior. Ten Tsai et al. [24], Saleem et al. [9] and Murthy [11] shows the result of their research that the effect of self-efficacy on organizational commitment has a positive effect.

H2: Self-efficacy has a significant effect on organizational commitment.

\section{The Influence of Organizational Commitment on $O C B$}

Relationship between Organizational commitment and OCB there was since an employee with commitment organizational will tend to behave to increase his/her value and support the organization. Organ [18] states the affective commitment felt as a social mental feeling which will lead to OCB. Organizational commitment has a significant influence on OCB [16]. $\mathrm{OCB}$

H3: Organizational commitment has a significant effect on

\section{LITERATURE REVIEW}

\section{A. Quality of Work Life (QWL)}

Nanjundeswaraswamy and Swamy [25] associated QWL with job satisfaction, job involvement, motivation, productivity, health, safety and wellbeing, job security, competency development and balance between work and nonwork life. Beauregard [10] define QWL as job security reward system that better, higher pay, opportunity for growth, participative groups, organizational productivity,

There are eight major conceptual categories relating to QWL proposed by Walton as 1. Adequate and fair compensation, 2. Safe and healthy working conditions 3 Immediate opportunity to use and develop human capacities. 4. Opportunity for continued growth and security. 5. Social integration in the work organization. 6. Constitutionalism work organizations. 7. Work and total life space. 8. Social relevance of work life [2]. Walton Eight aspects from Walton in which employee's perceptions towards their work organizations could determine their QWL.

The definitions also emphasize the good feeling perceived from the interaction between the individuals and the work environment. Muftah and Lafi [26] defined QWL as the combination of physical, psychological, and social factors that influence employee's satisfaction. An indicator used to measure QWL is compensation, working condition, development of competency and leadership style. 


\section{B. Self-efficacy}

Self-efficacy defines from Bandura [27] as capabilities to execute of action, self-efficacy may influence one's behavior, the way of thinking and emotional reactions in a difficult situation.

Self-efficacy is a personal judgment of "how well one can execute courses of action to deal with prospective situations" [14]. According to Bandura [5], there are 3 dimensions to measure self-efficacy, namely magnitude related to the difficulty level of the task dealt with. The second dimension is a generality, it shows to what extent an individual is sure of his/her ability in various situations, from performing the duties he/she commonly does to a duty or situation which never been done or in a difficult and various situation. The third dimension is a strength which more pressures on the level of strength or individual stability to the beliefs. Several indicators used to measure self-efficacy is level, generality, and that strength itself.

\section{Organizational Commitment}

Organizational commitment defined by Porter et al. [15] as kind of attitudinal inclination toward the organization. Organizational Commitment have three type: 1) value commitment, 2) retention commitment, 3) effort commitment.

Organizational commitment has three components, proposed from Meyer and Allen [19] affective commitment, 2) continuous commitment, and 3) normative commitment refers to commitment based on a moral belief or obligation that "it is the right and moral thing" to remain with the organization.

\section{Organizational Citizenship Behavior}

Organizational Citizenship Behavior (OCB) is a unique aspek of an individual activity at work. OCB are individual behavior that promote the goods of the organization, excamples, helping another employee, helpful to advice or suggestion [8].

$\mathrm{OCB}$ as an individual behavior that is decretionary, not directly OCB as an individual behavior that is discretionary, not directly or explicitly recognized by the formal reward system, and in the aggregate promotes the efficient and effective functioning of the organization [18]. Organ further elaborate thet OCBs exist in various forms, including altruism, courtesy, sportmenship, civic virtue and concienciousness [28]. Five dimensions OCB by Organ :

- Altruism, excample helping certain people in an organization with a relevant task or problem.

- Courtesy,

- Concienciousness,

- Civic Virtue

- Sportmanship,
Some of indicators used to measure nurse's OCB is in accordance with what Sofiah et al. propose in 2014 including altruism, civic virtue, courtesy, conscientiousness, and sportsmanship.

\section{METHODOLOGY}

\section{A. Methods}

This research was conducted to describe and test the hypothesis. This was a quantitative research. Being seen from its research purpose, this was categorized into an explanatory research which is a research which tries to test the relationship among variables through hypothesis testing. The method chosen was by doing a survey of the nurses at general hospitals in Malang.

\section{B. Data Collection and Sample}

This determination of research location used multi-stage area sampling, in which the location chosen was a general hospital in Malang City, Malang District, and Batu City. The next step is hospital determination in type A, B, C, and D. It randomly selected a hospital in Malang City, Malang District, and Batu City based on its type and finally got 4 hospitals, namely Saiful Anwar General Hospital in type A, persada Hosptal in Malng City in tipe B, Karsa Husada General Hospital in Batu City in type C, and Islamic Hospital Kasembon in Malang District in type D. We distributed 180 questionnaires. 175 of them were returned.

\section{Data Analysis}

Data that has been collected was then analyzed descriptively and inferentially. Data that is related to the respondent's answer was then analyzed descriptively with the assistance of SPSS analysis. While inferential analysis uses GSCA (Generalized Structured Component Analysis).

\section{Hypothesis Model}

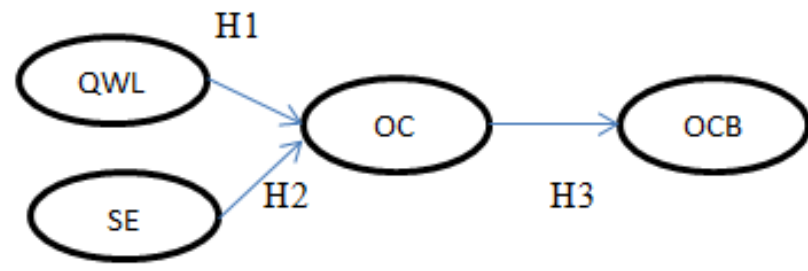

Fig. 1. Hypothesis model.

\section{RESULTS AND DISCUSSION}

Respondent data in this study are based on the workplace, gender, background level of education, age, years of service, service sector. Respondent data based on his workplace showed that nurses who worked at Saiful Anwar General Hospital were 135 respondents $(77.1 \%)$, nurses who worked at Persada Hospital were 13 respondents $(7.4 \%)$, nurses who worked at Karsa Husada General Hospital as many as 19 respondents 
$(10.9 \%)$ and nurses who worked at RSI Madinah as many as 8 respondents $(4.6 \%)$.

\section{A. Descriptive Analysis}

Based on data collected from the respondents' answer, an average indicator and variable from respondents' answer are as table 1 follows:

TABLE I. THE DistRIBUTION OF RESPONDENTS' PERCEPTION

\begin{tabular}{|l|l|l|}
\hline \multicolumn{1}{|c|}{ Variable } & \multicolumn{1}{|c|}{ Indicator } & \multicolumn{1}{c|}{$\begin{array}{c}\text { Average } \\
\text { scores }\end{array}$} \\
\hline \multirow{4}{*}{ QWL } & Compensation & 3.06 \\
\cline { 2 - 3 } & Working condition & 3.41 \\
\cline { 2 - 3 } & Competency Development & 3.51 \\
\cline { 2 - 3 } & Leadership style & 3.50 \\
\hline QWL variable average & 3.37 \\
\hline \multirow{4}{*}{ SE } & Level & 3.76 \\
\cline { 2 - 3 } & Generality & 3.46 \\
\cline { 2 - 3 } & Strength & 3.77 \\
\hline SE variable average & 3.66 \\
\hline \multirow{2}{*}{ Organizational } & Affective commitment & 3.45 \\
\cline { 2 - 3 } & Continued Commitment & 3.28 \\
\cline { 2 - 3 } & Normative commitment & 3.46 \\
\hline Organizational comment & atment variable average & 3.39 \\
\hline OCB & altruism & 3.66 \\
\hline \multicolumn{2}{|l|}{ Civic virtue } & 3.57 \\
\hline \multicolumn{2}{|l|}{ conscientiousness } & 3.83 \\
\hline \multicolumn{2}{|l|}{ courtesy } & 3.99 \\
\hline \multicolumn{2}{|l|}{ sportsmanship } \\
\hline OCB variable average & 3.76 \\
\hline
\end{tabular}

Source: processed primary data, 2019

Based on the respondents' answer to the QWL (X1) variable, it shows the average score is 3.37 . This indicates that QWL is in a good category. The average respondent's answer to the self-efficacy variable was by 3.66. This indicates that self-efficacy of the nurse is good/high. The average answer of respondents about organizational commitment variable was by 3.39. This indicates that the nurse's organizational commitment is in the good enough category. The average respondents' respond on OCB variable was by 3.76 . This indicates that the nurse's OCB is in the good/high category

\section{B. Hypothesis Testing}

Based on the inferential analysis result, it gets the result as follows:

TABLE II. THE RESUlTS OF HyPOTHESIS TESTING

\begin{tabular}{|l|l|l|l|l|l|}
\hline Exogenous & Endogenous & $\begin{array}{c}\text { Path } \\
\text { coefficient }\end{array}$ & SE & CR & Conclusion \\
\hline QWL & $\begin{array}{l}\text { Organizational } \\
\text { commitment }\end{array}$ & 0.209 & 0.095 & $2.197 *$ & Accepted \\
\hline SE & $\begin{array}{l}\text { Organizational } \\
\text { commitment }\end{array}$ & 0.251 & 0.082 & $3.067 *$ & Accepted \\
\hline $\begin{array}{l}\text { Organizat } \\
\text { ional } \\
\text { commitm } \\
\text { ent }\end{array}$ & OCB & 0.691 & 0.075 & $9.188^{*}$ & Accepted \\
\hline
\end{tabular}

Source: processed primary data, 2019
The result of hypothesis testing shows that there are a positive and significant influence of QWL on organizational commitment, self efficacy on organizational commitment and organizational commitment on OCB.

\section{The Influence of QWL on Organizational Commitment}

The results of this study are consistent with the opinion of Mayer and Allen [19] which states that a person's participation in organizational activities will influence their behavior in the workplace. Which is manifested in the form of organizational commitment. The results of this study are support the Social Exchange Theory [29] which states that someone behaves certain because of the exchange from the organization. In this study nurses have organizational commitment because the organization provider QWL to nurses in the form of compensation, working conditions, competency development and leadership.

That research results support the previous research conducted by Daud [20]; Ahmadi et al. [21], Farjad and Varnous [22], and Parvar et al. [23], which shows the result that QWL has a positive influence on commitment organizational.

\section{The Influnece of Self Efficacy on Organizational Commitment}

This research result is in accordance with the previous one conducted by Saleem et al. [9], Murthy [11], and Ten Tsai et al. [24] show that there is a positive and significat influence on commitment organizational.

This research result is in accordance with Murthy's [11] result stating that high self-efficacy will create an effective commitment. The results of this study are in accordance with Bandura's [5] social cognitive theory which states that self efficacy influences a person's behavior in the form of organizational commitment.The result of the descriptive analysis shows that the nurse's self-efficacy is good/high, this indicates that the nurse's beliefs about his/her ability to perform his/her duties are good. The nurse's organizational commitment based on the descriptive analysis is still good. For that matter, the nurse's organizational commitment can be more increased; one of them is increasing self-efficacy.

\section{E. The Influence of Commitment Organizational on $O C B$}

This research result is in accordance with Zainabadi's and Bakhsi's [16] idea which states that there is a positive relationship between organizational commitment and OCB because an employee having organizational commitment will tend to behave to increase his/her value and support organization. Organ [18] states that affective commitment felt is a mental feeling of social which will lead to OCB. The results of this study support the TRA / TPB where work attitudes (organizational commitment) influence one's behavior in the form of OCB [30].

Based on the result of the descriptive analysis, it is known that the organizational commitment of the nurse is quite good, 
while the nurse's OCB is good/high. The nurses' organizational commitment can be increased through increasing more organizational commitment, both affective commitment, continued commitment and normative commitment. All of behaviors of the nurse's OCB is good/high. It can be seen from the good behavior of nurse's altruism, good behavior of nurse's civic virtue, good behavior of nurse's conscientiousness, nurse's courtesy behavior is good/high too, and sportsmanship behavior of the nurse is also good.

\section{CONCLUSION AND Future SCOPE}

Conclusion of my reseach that there are a significant and positive influence of QWL on commitment organizatonal, self efficacy on commitment organizational and commitment organizational on OCB. The factor that infulence OCB nurses are QWL, Self efficacy and organizational commitment.

This research has a limitation, that is, it does not differentiate between government public hospitals and private public hospitals so that data bias is possible. Future studies can be carried out in public or private hospitals, to avoid biased data.

\section{REFERENCES}

[1] A.A. Majbel, M.K. Almsafir, R.S. Siron, and A.S.M. Alnaser, "The Drivers of Quality of Working Life (QWL): A Critical Review." Australian Journal of Basic and Applied Sciences, vol. 7, no. 10, pp. 398-405, 2013

[2] Kanten and Sadullah, "An Empirical Research on Relationship Quality of Work Life and Work Engagement." Procedia - Social and Behavioral Sciences, vol. 62, pp. $360-366,2012$

[3] M. Cheng Lai and Y. Chun Chen, "Self-Efficacy, Effort, Job Performance, Job Satisfaction, and Turnover Intention: The Effect of Personal Characteristics on Organization Performance." International Journal of Innovation, Management and Technology, vol. 3, no. 4, pp. $387-391,2012$.

[4] I. Ruhana, E.S. Astuti, H.N. Utami, and T.W. Afrianty, "The influence of Quality of Work Life (QWL) and Self Efficacy on Job Satisfaction, Organizational Commitment and Organizational Citizenship Behavior (OCB) (Study on Nurse Hospital in Malang)," Disertation, 2019.

[5] A. Bandura, Self-Efficacy, The Exercise of Control. New York: Freeman, 1997.

[6] M.U. Hassan, R. Kibria, and K. Nawas, "The Effects of Personal Characteristics on Organizational Commitment Through Job Satisfaction: An Empirical Study of Pakistan's Financial Sector." Middle-East Journal of Scientific Research, vol. 16, no. 7, pp. 942-951, 2013.

[7] F. Tojjari, M.R. Esmaeili and R. Bavandpour, "The Effect of SelfEfficacy on Job Satisfaction of Sport Referees Pelagia Research Library." European Journal of Experimental Biology, vol. 3, no. 2, pp. 219-225, 2013

[8] M.G. Shahnawaz, M.D. Jafri, and Hassan, "Psychological Capital as Predictors of Organizational Commitment and Organizational Citizenship Behaviour." Journal of the Indian Academy of Applied Psychology, vol. 35, pp. 78-84, 2009.

[9] A. Saleem, G. Saba, and A. Adnan, "Self-Efficacy and Optimism as Predictors of Organizational Commitment among Bank Employees." International Journal of Research Studies in Psychology, vol. 2, no. 2, pp. 33-42, 2013
[10] T.A. Beauregard, "Perfectionism, Self-Efficacy and OCB: The Moderating Role of Gender.” Personnel Review, vol. 41, no. 5, pp. 590608, 2012.

[11] R.K. Murthy, "Self-Efficacy, Work Engagement and Organizational Commitment." Global Journal of Multidisciplinary Studies, vol. 3, no. 6, pp. $113-124,2014$

[12] U. Rahman, Sulaiman, W. Shahrazad, R. Nasir, and F. Omar, "The Role of Job Satisfaction as Mediator in the Relationship between SelfEfficacy and Organizational Citizenship Behavior among Indonesian Teachers." International Journal of Business and Social Science, vol. 5, no. 9 , pp. $255-261,2014$.

[13] H. Mahrughy and R. Yadegar, "Examine the Relationship between SelfEfficacy Perception and Organizational Citizenship Behavior of Managers and Assistants (Case Study:School's Managers And Assistants Of Zabarkhan Area Of Neyshabur).” International Journal of Advanced Biotechnology and Research (IJBR), vol. 7, no. 4, pp. 891$895,2016$.

[14] A. Cohen and M Abedallah, "The Mediating Role of Burnout on the Relationship of Emotional Intelligence and Self-Efficacy with OCB and Performance.” Management Research Review, vol. 38, no. 1, pp. 2-28, 2015.

[15] L.W. Porter and E.E. Lawler, Managerial Attitudes and Performance. Illinois: Irwin-Dorsey Homewood, 1968

[16] A. Bakhshi., A.D. Sharma, and K. Kumar, "Organizational Commitmen as Predictor of Organizational Citizenship Behavior.” European Journal of Business and Management, vol. 3, no. 4, pp. 78 -86, 2011.

[17] Neeta, "Organizational Citizenship Behavior of Faculties in Private Engineering Colleges W.E.F Lucknow.” IJMBS, vol. 3, no. 1, pp. 116 123,2013

[18] D.W. Organ, "A Restatement of The Satisfaction-Performance Hypothesis." Journal of Management, vol. 14, no. 4, pp. 547-557, 1988.

[19] J. Meyer and N. Allen, Commitment In The Workplace. London: Sage Publications, 1997.

[20] N. Daud, "Quality of work life and organizational commitment amongs academic staff: Empirical evidence from Malaysia." In 2010 International Conference on Education and Management Technology pp. 271-275. IEEE, 2010.

[21] M.H. Zare, B. Ahmadi, A.A. Sari, M. Arab, and E.M. Kor, "Quality of working life on residents working in hospitals." Iranian journal of public health, vol. 41 , no. 9 , p. $78,2012$.

[22] H.R. Farjad and S. Varnous, "Study of relationship of quality of work life (QWL) and organizational commitment." Interdisciplinary Journal of Contemporary Research in Business, vol. 4, no. 9, pp. 449-456, 2013.

[23] M.R.F. Parvar, S.M. Allameh, and R. Ansari, "Effect of quality of work life on organizational commitment by SEM (case study: OICO company)." International Journal of Academic Research in Business and Social Sciences, vol. 3, no. 10, p. 135, 2013

[24] M.T. Tsai, C.L. Tsai, and Y.C. Wang, "A study on the relationship between leadership style, emotional intelligence, self-efficacy and organizational commitment: A case study of the Banking Industry in Taiwan.” African Journal of Business Management, vol. 5, no. 13, pp. 5319-5329, 2011

[25] T.S. Nanjundeswaraswamy and D.R. Swamy, "Quality Of Worklife Of Employees In Private Technical Institutions." International journal for quality research, vol. 7, no. 3, 2013.

[26] H. Al Muftah and H. Lafi, "Impact of QWL on employee satisfaction case of oil and gas industry in Qatar." Advances in management and applied economics, vol. 1, no. 2, p. 107, 2011.

[27] A. Bandura, Social Foundations of Thought and Action: A Social Cognitive Theory. Englewood Cliffs, NJ: Prentice-Hall, 1986.

[28] K.K. Sofiah, P. Padmashantini, and K. Gengeswari, "A Study on Organizational Citizenship Behavior in Banking Industry." International Journal for Innovation Education and Research, vol. 2, no. 7, pp. 73 82,2014

[29] R. Cropanzano and M.S. Mitchell, "Social Exchange Theory:An Interdisciplinary Review.” Journal of Management, vol. 31, no. 6, pp. 874-900, 2005.

[30] M.D. Truxillo, N.T. Bauer, and B. Erdogan, Psychology and Work. Perpektive on Industrial and Organizational Psychology. Rautledge Taylor and Francis Group. New York and London, 2016 